Article

\title{
Effects of Graphene Nanoplatelets and Cellular Structure on the Thermal Conductivity of Polysulfone Nanocomposite Foams
}

\author{
Hooman Abbasi ${ }^{\mathbb{D}}$, Marcelo Antunes ${ }^{\mathbb{D}}$ and José Ignacio Velasco *(D) \\ Department of Materials Science and Engineering, Technical University of Catalonia (UPC BarcelonaTech), \\ ESEIAAT, C/Colom 11, E-08222 Terrassa, Spain; hooman.abbasi@upc.edu (H.A.); \\ marcelo.antunes@upc.edu (M.A.) \\ * Correspondence: jose.ignacio.velasco@upc.edu; Tel.: +34-937398152
}

Received: 21 November 2019; Accepted: 18 December 2019; Published: 20 December 2019

\begin{abstract}
Polysulfone (PSU) foams containing 0-10 wt \% graphene nanoplatelets $(\mathrm{GnP})$ were prepared using two foaming methods. Alongside the analysis of the cellular structure, their thermal conductivity was measured and analyzed. The results showed that the presence of $\mathrm{GnP}$ can affect the cellular structure of the foams prepared by both water vapor induced phase separation (WVIPS) and supercritical $\mathrm{CO}_{2}\left(\mathrm{scCO}_{2}\right)$ dissolution; however, the impact is greater in the case of foams prepared by WVIPS. In terms of thermal conductivity, the analysis showed an increasing trend by incrementing the amount of $\mathrm{GnP}$ and increasing relative density, with the tortuosity of the cellular structure, dependent on the used foaming method, relative density, and amount of GnP, playing a key role in the final value of thermal conductivity. The combination of all these factors showed the possibility of preparing PSU-GnP foams with enhanced thermal conductivity at lower GnP amount by carefully controlling the cellular structure and relative density, opening up their use in lightweight heat dissipators.
\end{abstract}

Keywords: polysulfone foams; graphene; thermal conductivity; tortuosity; water vapor induced phase separation; $\mathrm{scCO}_{2}$

\section{Introduction}

Polysulfone (PSU) is a high performance thermoplastic with high thermal and chemical stability, excellent strength and toughness, good environmental stress-crack resistance, and inherent fire resistance [1,2]. Additionally, it is resistant to gamma and e-beam radiation due to its high aromatic content [3]. PSU foaming methods such as carbon dioxide dissolution foaming [4-8], extrusion of microcellular polysulfone using chemical blowing agents [9] and PSU membrane formation [10-13] have been vastly studied. Nevertheless, the addition of thermally conductive nanofillers such as graphene is still incipient [14].

The high aspect ratio of carbon-based nanofillers allows the preparation of polymer-based nanocomposites with high performance and multifunctionality [15]. Their addition to polymers can provide thermal and electrical conductivity at low nanofiller content, overcoming one of the major technological barriers of polymers and enabling their use in applications such as heat sinks [16] and electronic packaging [17]. Additionally, these nanocomposites are suitable candidates as alternatives to conductive polymers that lack thermal stability and proper mechanical performance [18].

The thermal conductivity of nanocomposites is highly dependent on the filler and polymer type [19]. Other factors such as purity and dimension of the filler, polymer crystallinity and measuring methods, explain the scattered data reported for the thermal conductivity of nanocomposites $[18,20]$. Previous studies of such materials are focused mainly on various types of carbon-based fillers, owing to 
their intrinsically high thermal conductivity [21-23]. Among them, graphene nanoplatelets (GnP) have been some of the most considered nanofillers in recent studies for enhancing the thermal conductivity of polymer-based nanocomposites [24-26]. However, results suggest certain constraints regarding the improvement of thermal conductivity, as nanocomposites prepared with GnP have shown limited thermal conductivity even at high filler content [27].

Foaming of these nanocomposites has been the center of attention with the goal of creating novel foams with improved specific properties. In this sense, we have previously investigated thoroughly the preparation and properties of foams based on other high performance thermoplastics like polyetherimide (PEI) reinforced with GnP and carbon nanotubes [28-31]. The results presented in these works indicate that foaming provided further enhancement of the electrical conductivity by promoting a better dispersion of the nanofillers through the continuous phase of the nanocomposite foams [29].

Likewise, a great interest has appeared very recently regarding the possibility of tuning and enhancing the thermal conductivity of polymer-based foams and hence extend their applicability by generating a more effective thermal conduction network throughout the polymer cell walls by means of guaranteeing a proper distribution and dispersion of thermally conductive nanoparticles, such as GnP. Foaming could hence provide a viable strategy for developing tailored structures to enhance the heat dissipation efficiency of novel lightweight devices. In this sense, PSU nanocomposite foams containing variable concentrations of $\mathrm{GnP}$ (up until $10 \mathrm{wt} \%$ ) were prepared using two foaming methods: water vapor induced phase separation (WVIPS) and $\mathrm{scCO}_{2}$ dissolution. The resulting foams were characterized regarding their cellular structure and thermal conductivity.

The novelties of the present research are (1) the comparison between two very different foaming methods as is the common method of $\mathrm{scCO}_{2}$ dissolution foaming with the less common method of water vapor induced phase separation, usually considered for preparing polymeric membranes [32], with obvious advantages of the second one such as the non-requirement of having to melt-compound the material or the possibility of controlling in an easy way the density and cellular structure of the resulting foams; and (2) the consideration for the first time of how the addition of variable amounts of $\mathrm{GnP}$ and the developed cellular structure affect the thermal conductivity values through a tortuosity factor that takes into account the complexity of the cellular structure. By considering this tortuosity factor and the relative density as fundamental parameters in the final thermal conductivity, our work shows the possibility of optimizing the thermal conductivity of PSU-GnP foams through the control of their density and cellular structure, ultimately related to the possibility of obtaining conductive foams at lower $\mathrm{GnP}$ amounts, for instance for lightweight heat dissipation components.

\section{Materials and Methods}

\subsection{Materials}

PSU pellets (UDEL P-1700) were purchased from Solvay (Brussels, Belgium) with a density of $1.24 \mathrm{~g} / \mathrm{cm}^{3}$ and a glass transition temperature of $185^{\circ} \mathrm{C}$. The $\mathrm{GnP}$ used in this study was acquired from XG Science Inc. (Lansing, MI, USA) with the commercial name of xGnP-Grade M15. These nanoplatelets have a reported thickness of 6-8 nm, an average platelet diameter of $15 \mu \mathrm{m}$, a surface area of $120-150 \mathrm{~m}^{2} / \mathrm{g}$, a density of $2.2 \mathrm{~g} / \mathrm{cm}^{3}$, and a thermal conductivity of 3000 and $6 \mathrm{~W} \cdot \mathrm{m}^{-1} \cdot \mathrm{K}^{-1}$ parallel and perpendicular to the surface, respectively. $\mathrm{N}$-methyl pyrrolidone (NMP) used in this study was obtained from Panreac Química SA (Barcelona, Spain) with 99\% purity and a boiling and flash points of 202 and $95^{\circ} \mathrm{C}$, respectively.

\subsection{Foaming Methods}

Three series of foams were prepared in this study, the first two using the WVIPS method. In this method, graphene nanoplatelets were initially dispersed in NMP for 30 minutes using a FB-705 ultrasonic processor (Fisher Scientific, Hampton, NH, USA) at maximum amplitude using a $12 \mathrm{~mm}$ 
solid tip probe and $20 \mathrm{kHz}$, applying a total amount of energy of $90 \mathrm{~kJ}$ at $95-130 \mathrm{~W}$. The temperature of this NMP-GnP solution was maintained at $50{ }^{\circ} \mathrm{C}$ using an ice-bath. PSU was then dissolved in the NMP-GnP solution at $15 \mathrm{wt} \%$ PSU concentration for the first foam series (series 1) and $25 \mathrm{wt} \%$ PSU for the second one (series 2) at $50{ }^{\circ} \mathrm{C}$ and kept stirring at $450 \mathrm{rpm}$ for $24 \mathrm{~h}$. Foamed samples were respectively coded as " 15 PSU x GnP" and "25 PSU x GnP", with x representing GnP's weight percentage. In the following step, the solutions were poured on a flat glass and kept at room temperature exposed to air with an average humidity of $75 \%$ for 6 days. Foams with variable GnP content $(0,1,2,5$ and $10 \mathrm{wt} \%$ ) were prepared for both series. The phase inversion between the solution and water led to the formation of the cellular structure. The resulting foams were then washed in water and ethanol in order to remove the residual solvent and afterwards dried in a vacuum dryer. The process is shown in Figure 1.

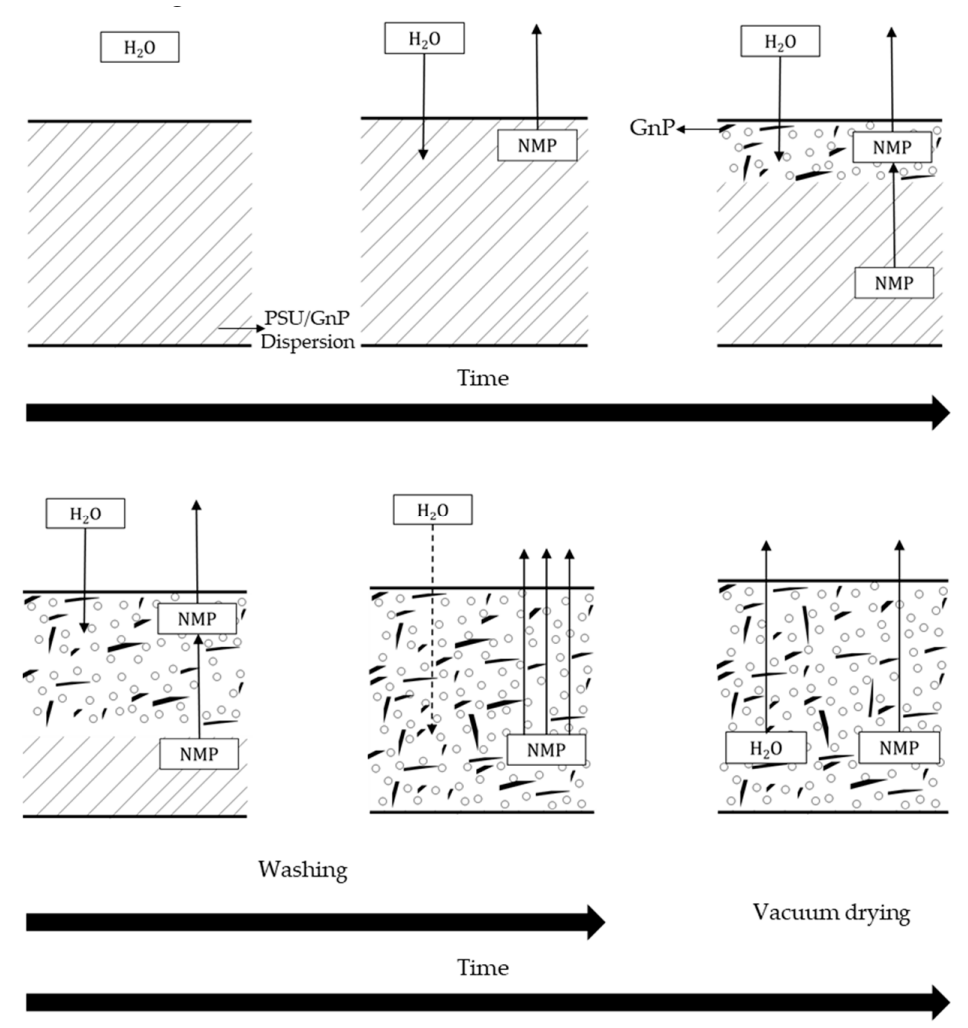

Figure 1. Scheme of the water vapor induced phase separation (WVIPS) process used to prepare PSU-GnP foams from series 1 (15 wt \% PSU) and series 2 ( $25 \mathrm{wt} \%$ PSU).

A third series of PSU-GnP nanocomposite foams (series 3) were prepared by initially melt-compounding PSU pellets and GnP powder using a Brabender Plastic-Corder (Brabender $\mathrm{GmbH}$ and Co., Duisburg, Germany) and foamed using $\mathrm{scCO}_{2}$ dissolution foaming inside a high pressure vessel. In order to prepare foams with variable GnP content $(0,0.4,0.7,1.0,1.5$ and $2 \mathrm{wt} \%)$, a masterbatch containing $50 \mathrm{wt} \%$ of ultrasonicated GnP in PSU was initially prepared in an NMP solution and then washed and dried. This masterbatch was then melt-mixed with PSU pellets in the Brabender in order to obtain the desired compositions. Subsequently, the nanocomposites were removed from the Brabender mixing chamber and molded into circular-shaped disks (foam precursors) using a hot-plate press (PL15, IQAP LAP, IQAP Masterbatch Group S.L., Barcelona, Spain) at $250{ }^{\circ} \mathrm{C}$ and $80 \mathrm{bar}$ for $14 \mathrm{~min}$. The resulting disks had a nominal thickness of $3 \mathrm{~mm}$ and a diameter of $74 \mathrm{~mm}$.

Foaming took place in the high-pressure vessel (CH-8610 Uster/Schweiz, Büchiglasuster, Switzerland) by dissolving $\mathrm{scCO}_{2}$ at $185{ }^{\circ} \mathrm{C}$ and $180-210$ bar for $5 \mathrm{~h}$, followed by a sudden depressurization at $\sim 0.3 \mathrm{MPa} / \mathrm{s}$ and controlled cooling of the vessel using circulating water. Both steps 
of $\mathrm{scCO}_{2}$ dissolution/heating and depressurization/cooling are shown in Figure 2. Foams from this series were coded as "PSU x GnP" (x representing the weight percentage of GnP).

1. $\mathrm{CO}_{2}$ dissolution/heating

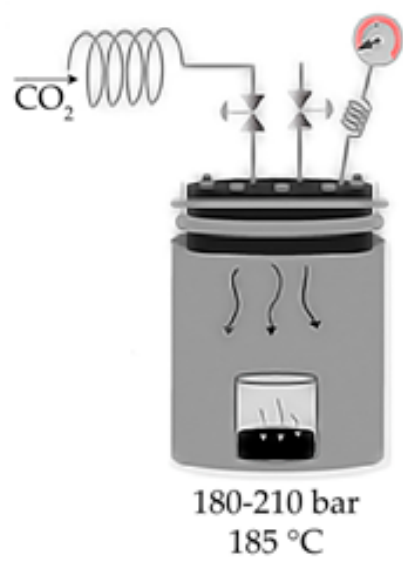

2. $\mathrm{CO}_{2}$ depressurization/cooling

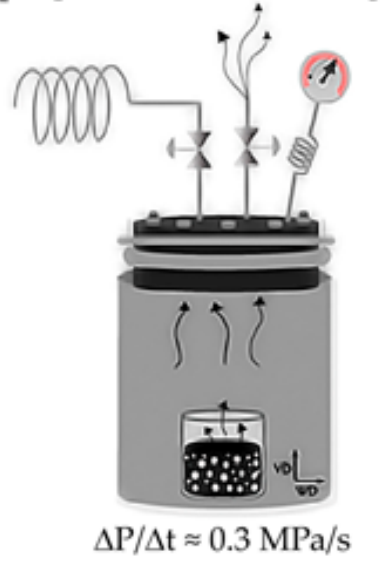

Figure 2. Scheme of the $\mathrm{scCO}_{2}$ dissolution foaming process used to prepare PSU-GnP foams from series 3.

\subsection{Testing Procedure}

The foam's density values were measured using the ISO-845 standard procedure. The cellular structure of the foams was analyzed using a JEOL JSM-5610 (Tokyo, Japan) scanning electron microscope (SEM) applying a voltage of $10 \mathrm{kV}$ and a working distance of $40 \mathrm{~mm}$. Samples were brittle-fractured using liquid nitrogen and later coated with a thin layer of gold by sputter deposition using a BAL-TEC SCD005 (Los Angeles, CA, USA) sputter coater under an argon atmosphere. The values of the average cell size $(\Phi)$ were measured using the intercept counting method, explained in detail in [33]. Five $\times 300$ magnification SEM micrographs were used for each foam. Cell nucleation density $\left(N_{0}\right)$ and cell density $\left(N_{\mathrm{f}}\right)$, which respectively represent the number of cells per volume of unfoamed material and the number of cells per volume of foamed material, were calculated assuming an isotropic distribution of spherical cells according to:

$$
\begin{gathered}
N_{0}=\left(\frac{n}{A}\right)^{\frac{3}{2}}\left(\frac{\rho_{\mathrm{s}}}{\rho}\right), \\
N_{\mathrm{f}}=\frac{6}{\pi \Phi^{2}}\left(1-\frac{\rho}{\rho_{\mathrm{s}}}\right),
\end{gathered}
$$

where $n$ is the number of cells in the micrograph, $A$ is its area in $\mathrm{cm}^{2}$, and $\rho_{\mathrm{s}}$ and $\rho$ are the solid and foam densities, respectively.

The thermal conductivity of PSU and PSU-GnP nanocomposites and foams was measured using a C-Therm TCi Thermal Conductivity Analyzer, which employs the Modified Transient Plane Source technique, with a sensor radius of $3.189 \mathrm{~mm}$, optimizing both the power output and measuring time according to the thermal characteristics of each sample (0.005-0.015 W and $15-80 \mathrm{~s}$, respectively). The samples were prepared with the following dimensions: $20 \mathrm{~mm} \times 20 \mathrm{~mm} \times 2 \mathrm{~mm}$ (thickness), cutting directly from the obtained foams and flattening the surface using sandpaper.

\section{Results}

\subsection{Cellular Structure of the Foams}

The composition of PSU-GnP nanocomposite foams prepared by WVIPS (series 1 and series 2) and $\mathrm{scCO}_{2}$ dissolution (series 3 ), their respective relative density $\left(\rho / \rho_{\mathrm{s}}\right)$, and main cellular structure characteristics are presented in Table 1. 
Table 1. Composition, relative densities and cellular structure characteristics of PSU and PSU-GnP nanocomposite foams.

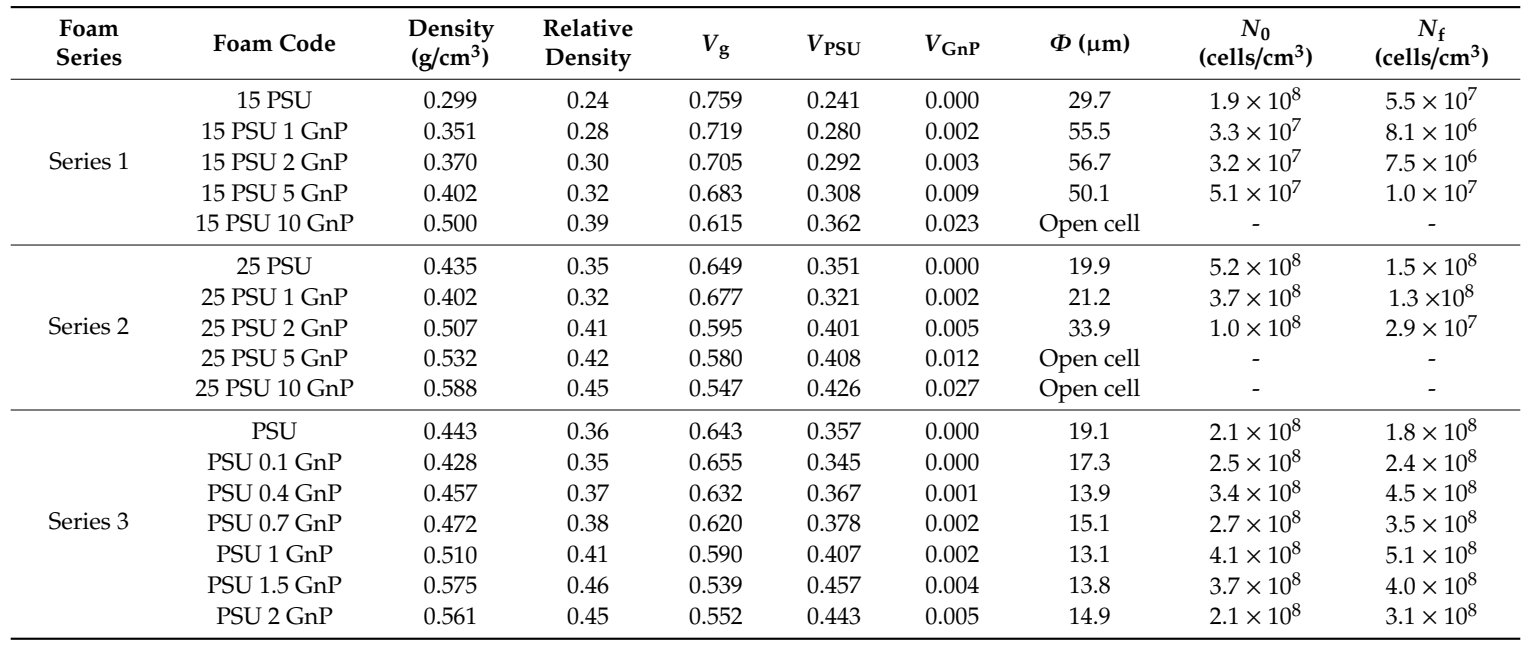

As can be seen in Table 1, the addition of GnP resulted in a general increase in the average cell size for foams prepared using the WVIPS method when compared to the unfilled PSU foams. The addition of $\mathrm{GnP}$ in the first two foam series, that is, those prepared by WVIPS, seemed to affect the kinetics of cell formation due to GnP's affinity for NMP, which slowed down the process by hindering the phase exchange with water. The greater amounts of $\mathrm{GnP}$ in these foams $(10 \mathrm{wt} \% \mathrm{GnP}$ in series 1 and 5 and 10 $\mathrm{wt} \% \mathrm{GnP}$ in series 2) resulted in the formation of foams with open interconnected pores, which could be the result of the mentioned GnP affinity for NMP (see micrographs presented in Figures 3 and 4).
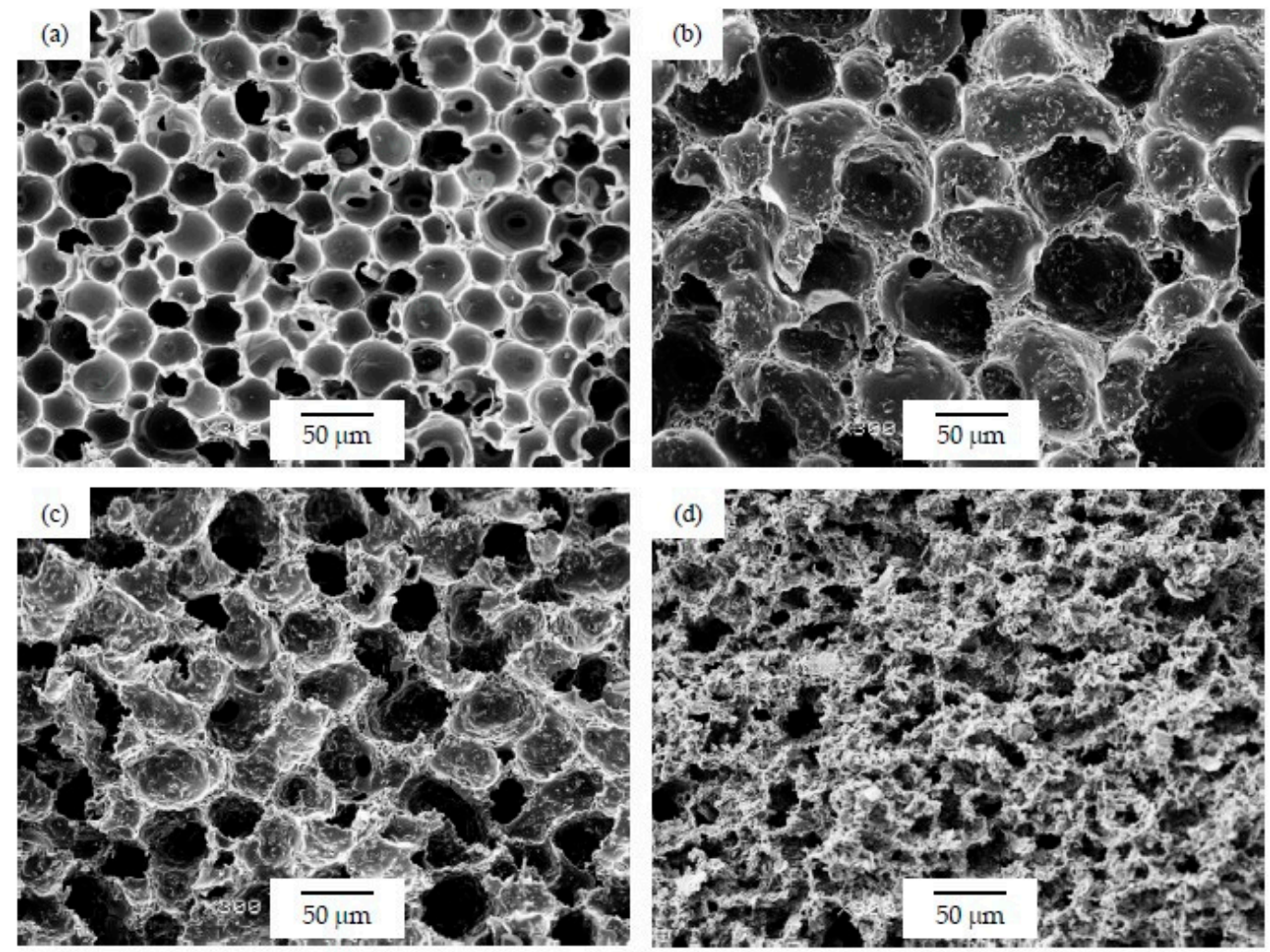

Figure 3. Micrographs at $\times 300$ magnification illustrating the cellular structure of PSU-GnP foams from series 1: (a) 15 PSU; (b) 15 PSU 2 GnP; (c) 15 PSU 5 GnP; and (d) 15 PSU 10 GnP. 

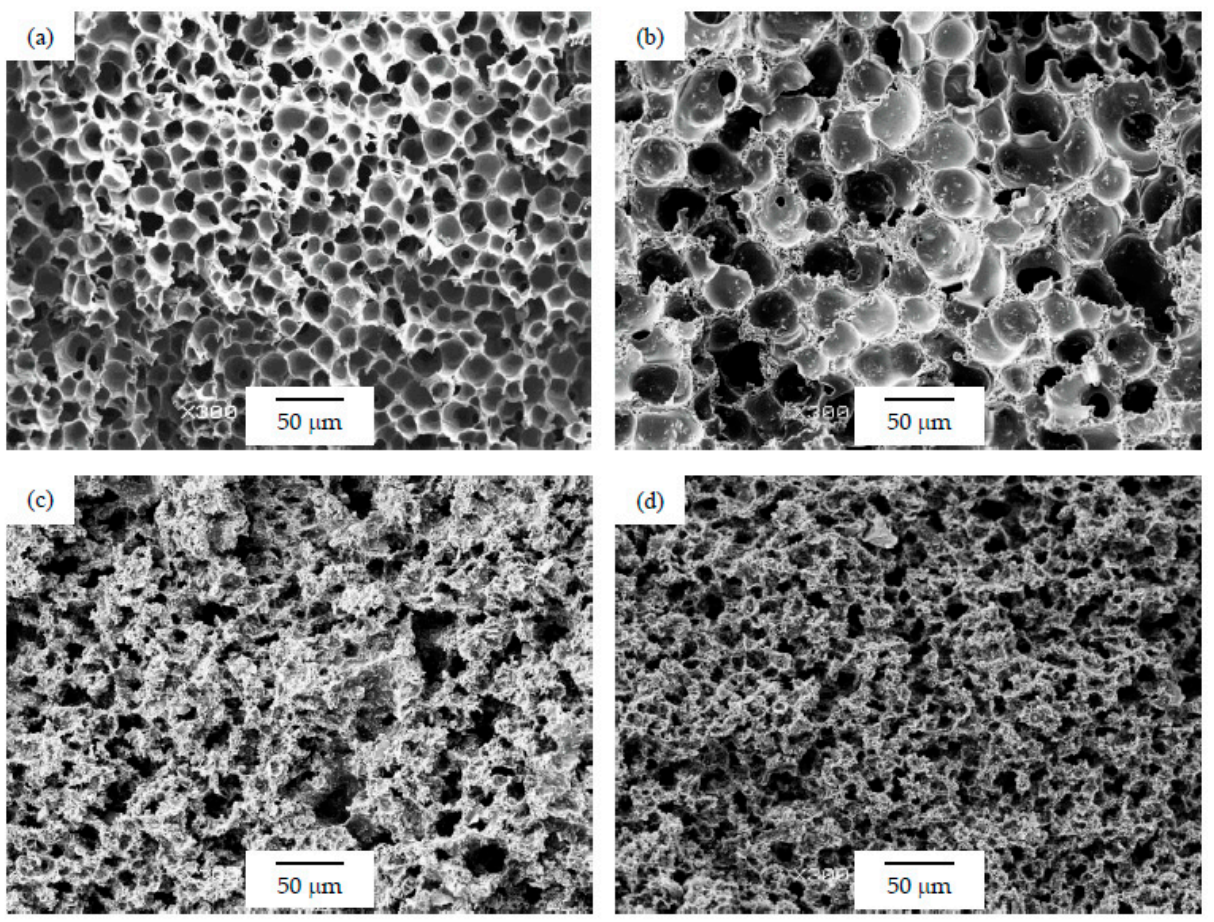

Figure 4. Micrographs at $\times 300$ magnification illustrating the cellular structure of PSU-GnP foams from series 2: (a) 25 PSU; (b) 25 PSU 2 GnP; (c) 25 PSU 5 GnP; and (d) 25 PSU 10 GnP.

Regarding the cellular structure of foams prepared via $\mathrm{scCO}_{2}$ dissolution (series 3), which displayed slightly smaller cell sizes than foams from series 1 and series 2, the addition of GnP resulted in a slight decrease of the average cell size when compared to the unfilled PSU foam (see Figure 5), which could be related to a barrier effect of the platelet-like $\mathrm{GnP}$ to the diffusion of $\mathrm{scCO}_{2}$. No cell size reduction was observed with further increasing the amount of GnP.
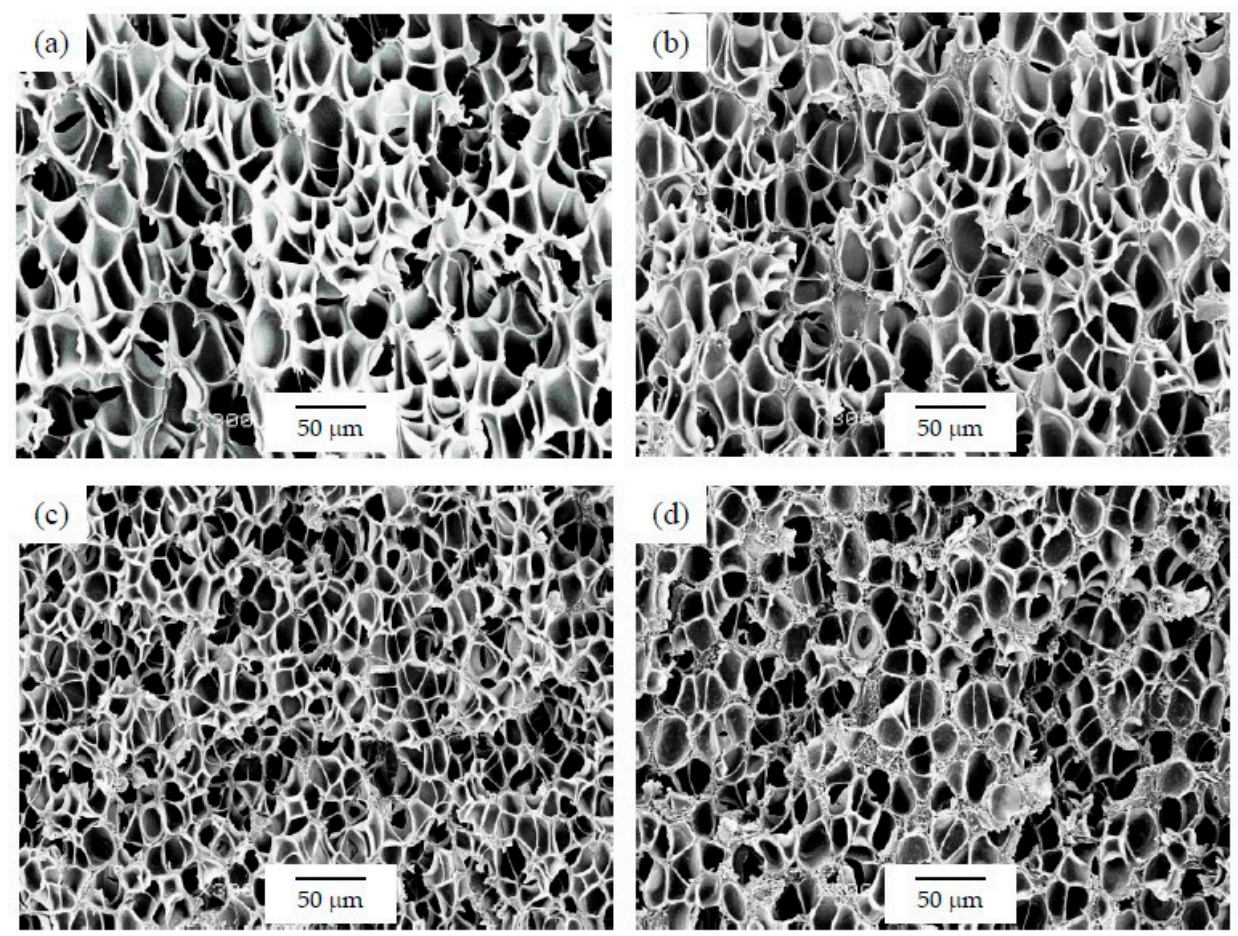

Figure 5. Micrographs at $\times 300$ magnification illustrating the cellular structure of PSU-GnP foams from series 3: (a) PSU; (b) PSU 0.4 GnP; (c) PSU 1 GnP; and (d) PSU 2 GnP. 
Cell density and cell nucleation density decreased for the first two series of foams with the addition of GnP when compared to the respective unfilled PSU foams. However, by increasing the amount of $\mathrm{GnP}$, these values did not follow a generic pattern. In a similar way, foams prepared by $\mathrm{scCO}_{2}$ dissolution displayed a general increase in cell density and cell nucleation density with adding GnP. Nevertheless, no clear trend was observed within these samples related to the increment in the amount of GnP.

\subsection{Thermal Conductivity}

The experimental thermal conductivity $\left(\lambda_{\exp }\right)$ of all foams and their relative density values are presented in Table 2.

Table 2. Experimental thermal conductivity values of PSU and PSU-GnP nanocomposite foams.

\begin{tabular}{cccc}
\hline Foam Series & Foam Code & Relative Density & $\lambda_{\text {exp }}\left(\mathbf{W} \cdot \mathbf{m}^{\left.\mathbf{- 1} \cdot \mathbf{K}^{-\mathbf{1}}\right)}\right.$ \\
\hline \multirow{5}{*}{ Series 1 } & 15 PSU & 0.24 & 0.056 \\
& 15 PSU 1 GnP & 0.28 & 0.073 \\
& 15 PSU 2 GnP & 0.30 & 0.073 \\
15 PSU 5 GnP & 0.32 & 0.111 \\
& 15 PSU 10 GnP & 0.39 & 0.193 \\
\hline \multirow{5}{*}{ Series 2 } & 25 PSU & 0.35 & 0.066 \\
& 25 PSU 1 GnP & 0.32 & 0.090 \\
& 25 PSU 2 GnP & 0.41 & 0.116 \\
& 25 PSU 5 GnP & 0.42 & 0.221 \\
& 25 PSU 10 GnP & 0.45 & 0.510 \\
\hline \multirow{5}{*}{ Series 3 } & PSU & 0.36 & 0.077 \\
& PSU 0.1 GnP & 0.35 & 0.072 \\
& PSU 0.4 GnP & 0.37 & 0.088 \\
& PSU 0.7 GnP & 0.38 & 0.087 \\
& PSU 1 GnP & 0.41 & 0.091 \\
& PSU 1.5 GnP & 0.46 & 0.102 \\
& PSU 2 GnP & 0.45 & 0.108 \\
\hline
\end{tabular}

As can be seen, there was a direct relation between the thermal conductivity and the GnP amount, as all PSU-GnP nanocomposite foams displayed an increasingly higher thermal conductivity with incrementing the amount of $\mathrm{GnP}$ (see Figure 6), owing to the inherently high thermal conductivity of $\mathrm{GnP}$ and the higher probability of physical contact between graphene nanoplatelets (see the $\times 1500$ magnification micrographs presented in Figures 7-9 and especially the comparative high magnification micrographs presented in Figure 10 showing the distribution and dispersion of $\mathrm{GnP}$ throughout the cell walls of PSU-GnP foams). No significant differences were observed in terms of GnP dispersion between foams with $2 \mathrm{wt} \% \mathrm{GnP}$ prepared by the two foaming methods (Figure 10). The experimental thermal conductivity of each foam series followed a linear trend with the volume percentage of $\mathrm{GnP}$ $\left(R^{2} \geq 0.93\right)$ with different slopes for each of the series (Figure 6). 


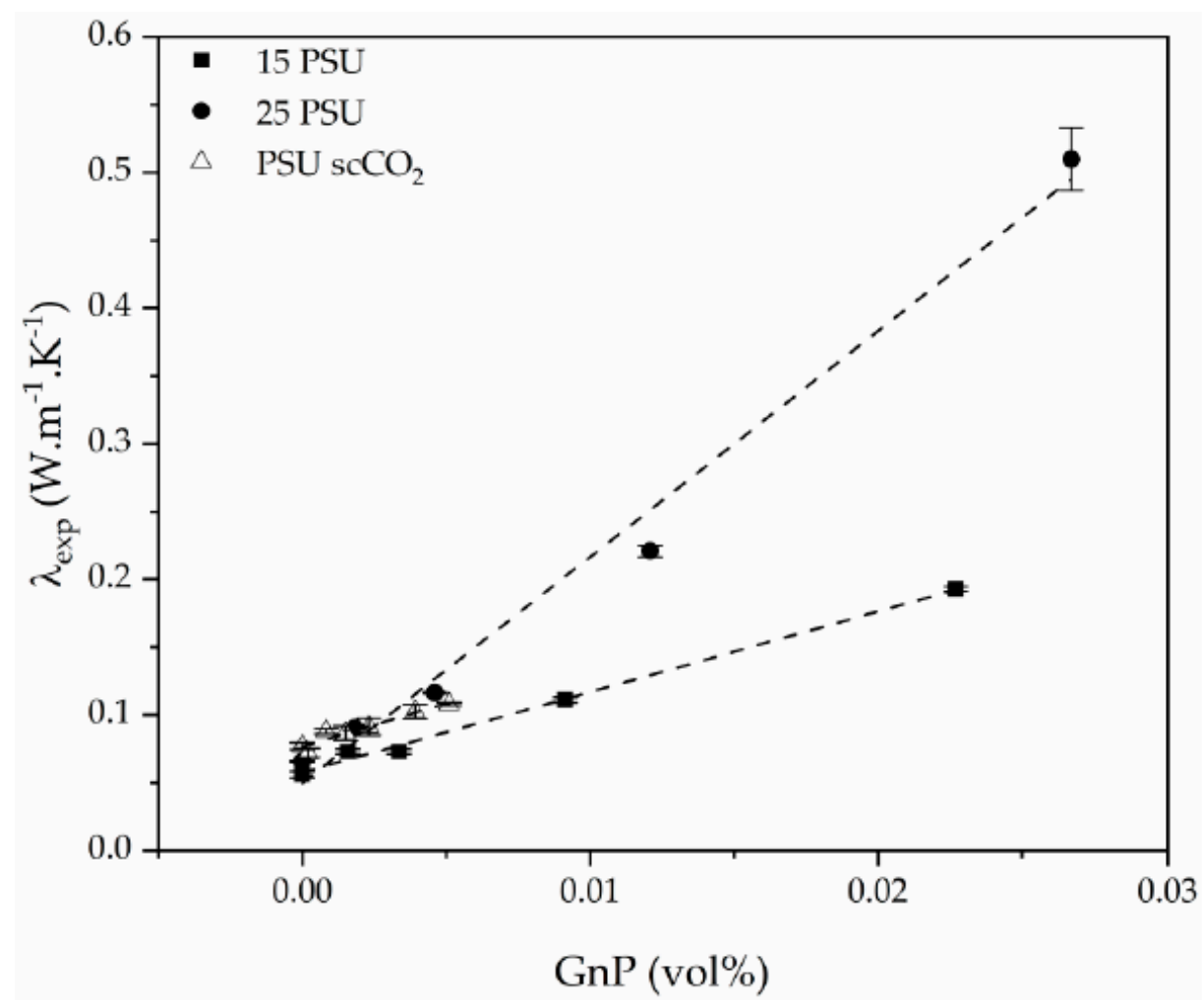

Figure 6. Experimental thermal conductivity enhancement of PSU and PSU-GnP nanocomposite foams with increasing GnP amount.
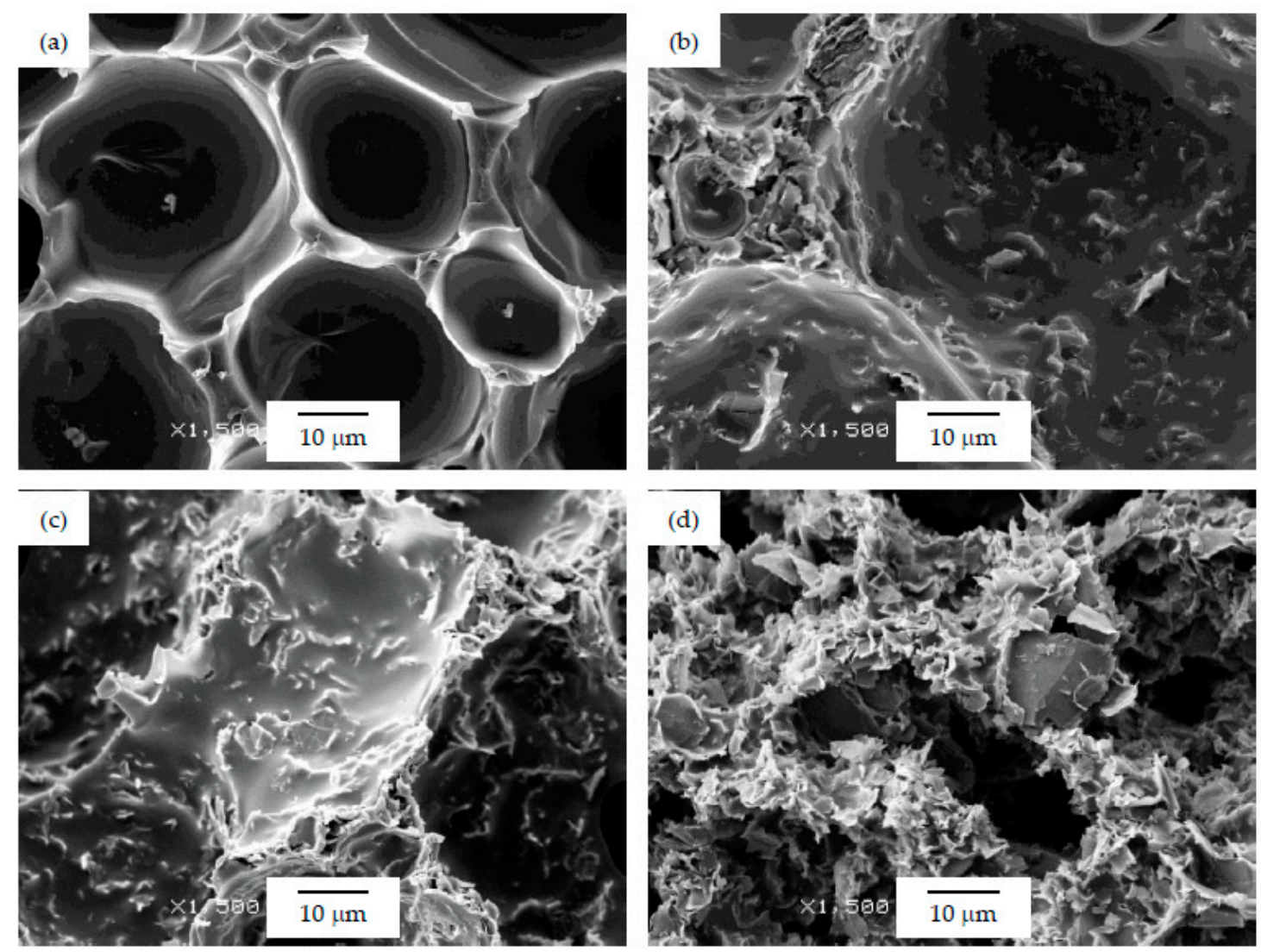

Figure 7. Micrographs at $\times 1500$ magnification illustrating the cell walls of PSU-GnP foams from series 1: (a) 15 PSU; (b) 15 PSU 2 GnP; (c) 15 PSU 5 GnP; and (d) 15 PSU 10 GnP. 

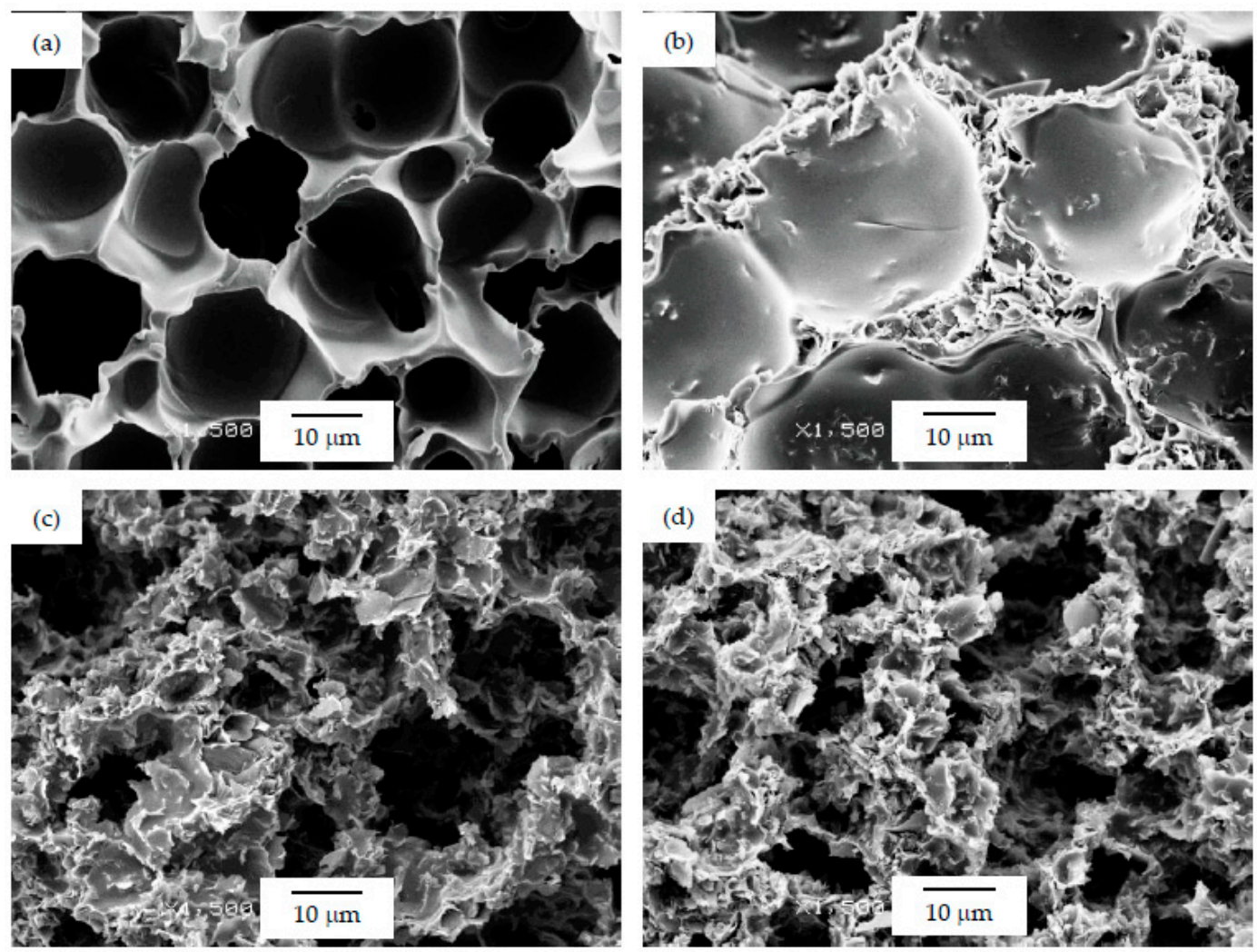

Figure 8. Micrographs at $\times 1500$ magnification illustrating the cell walls of PSU-GnP foams from series 2: (a) 25 PSU; (b) 25 PSU 2 GnP; (c) 25 PSU 5 GnP; and (d) 25 PSU 10 GnP.
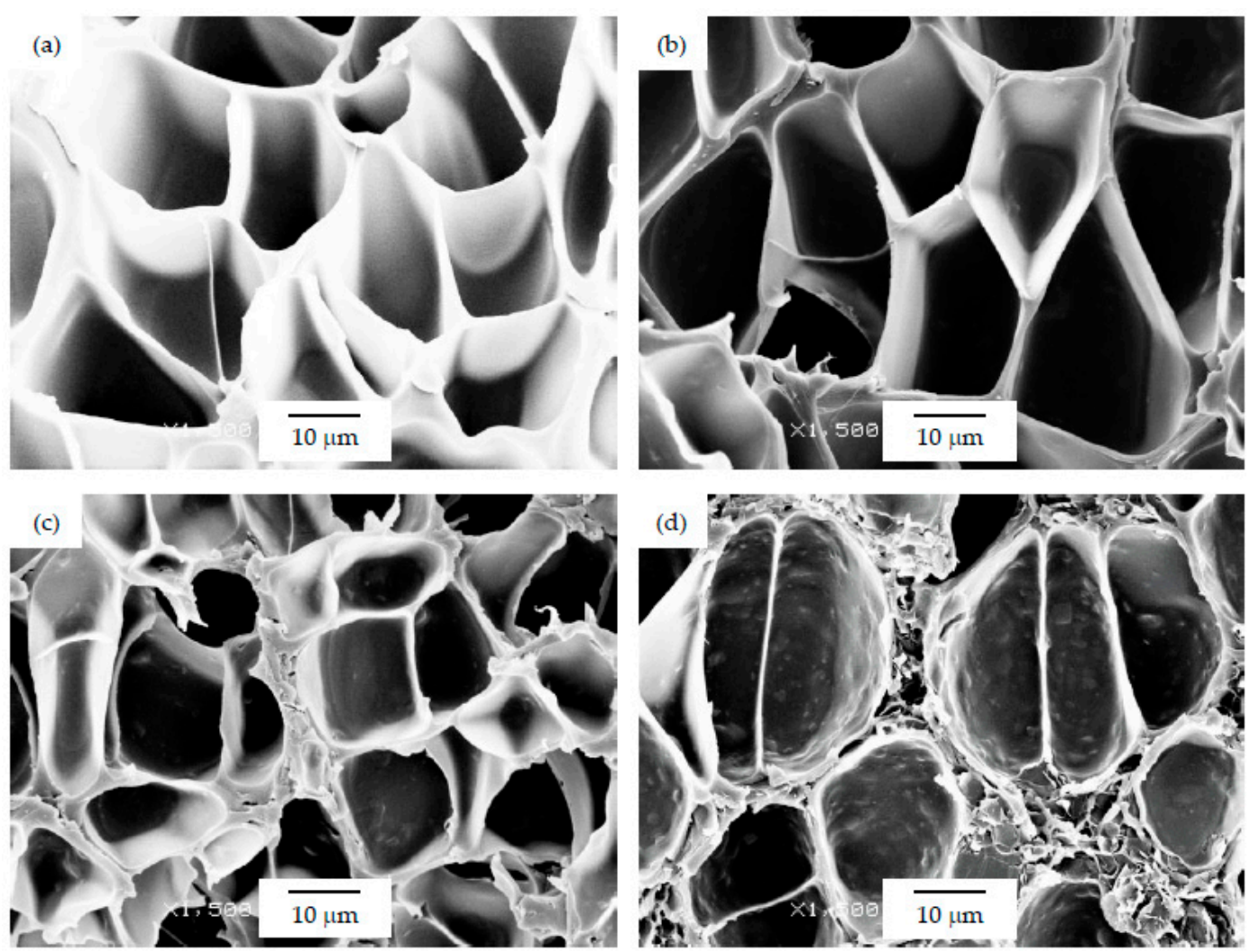

Figure 9. Micrographs at $\times 1500$ magnification illustrating the cell walls of PSU-GnP foams from series 3: (a) PSU; (b) PSU 0.4 GnP; (c) PSU 1 GnP; and (d) PSU 2 GnP. 

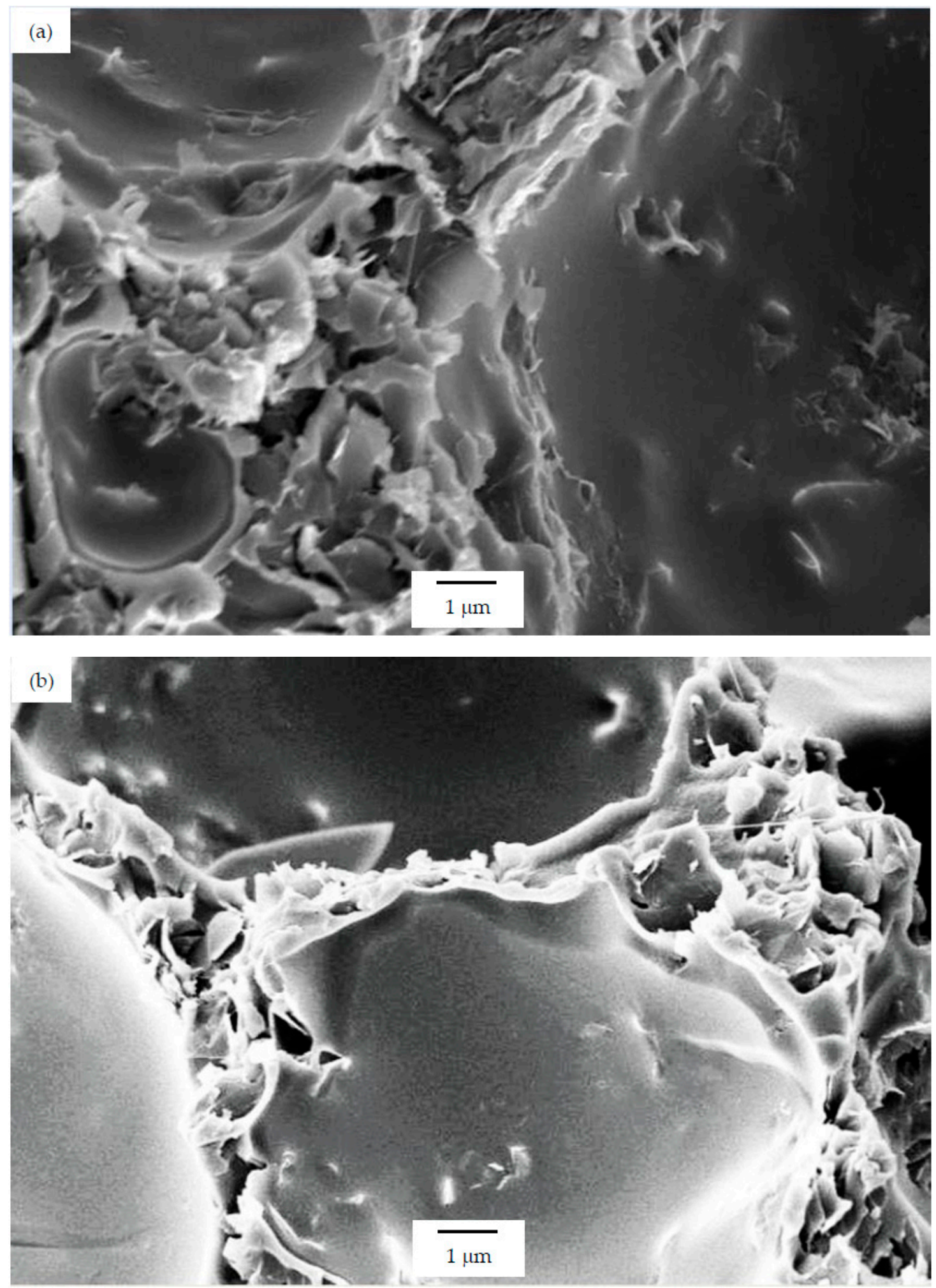

Figure 10. Cont. 


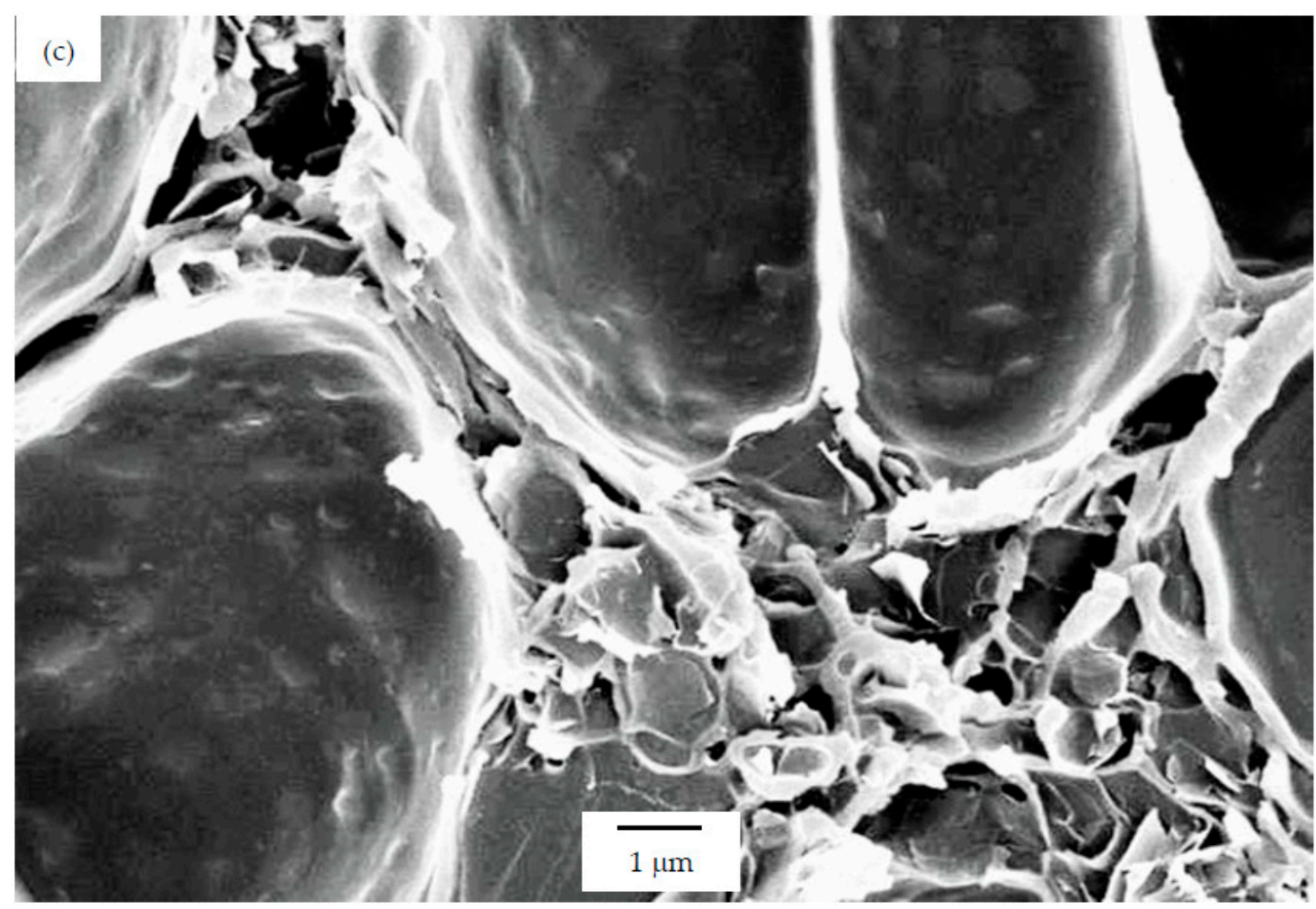

Figure 10. High-magnification micrographs $(\times 5000)$ illustrating the distribution and dispersion of $\mathrm{GnP}$ throughout the cell walls of PSU-GnP foams with $2 \mathrm{wt} \%$ GnP: (a) 15 PSU 2 GnP; (b) 25 PSU 2 GnP; and (c) PSU 2 GnP.

Relative density also played a significant role, as thermal conductivity augmented with increasing relative density (Figure 11), especially in the case of PSU-GnP foams from series 2 . This increment was related to the increasingly higher importance of thermal conduction through the solid phase, formed by a combination of PSU and thermally conductive GnP.

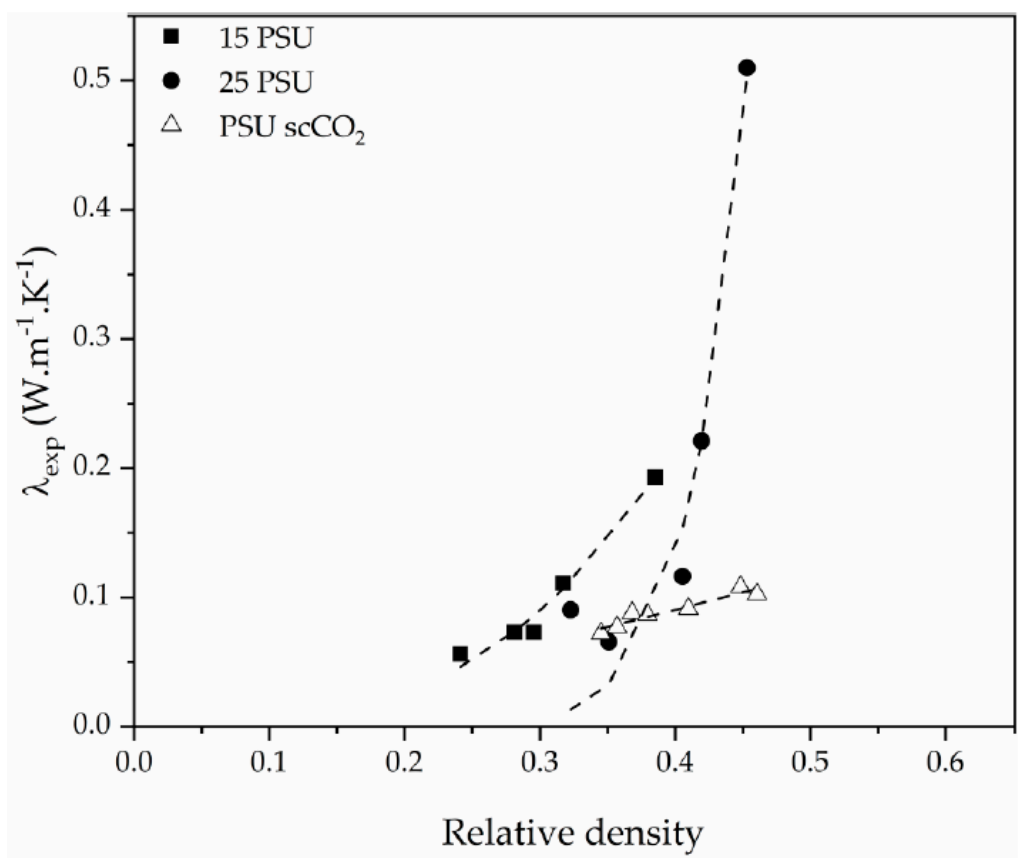

Figure 11. Experimental thermal conductivity enhancement of PSU and PSU-GnP nanocomposite foams with increasing relative density. 
The effect of GnP influence on the thermal conductivity of the foams regardless of the changes in relative density can be observed in Figure 12 by representing the specific experimental thermal conductivity $\left(\lambda_{\text {spec }}\right)$, defined as the quotient between the experimental thermal conductivity and the density of the foam, as a function of $\mathrm{GnP}$ amount.

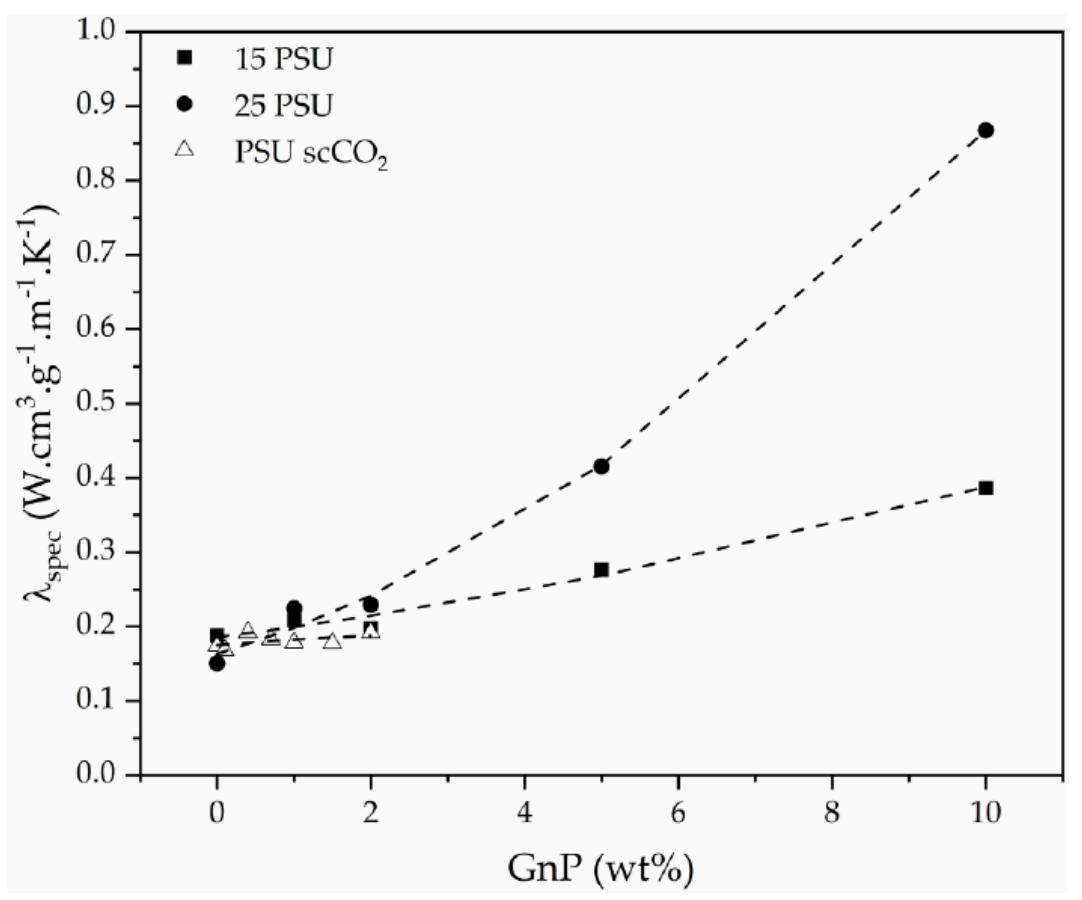

Figure 12. Specific experimental thermal conductivity evolution of PSU and PSU-GnP nanocomposite foams with increasing $\mathrm{GnP}$ amount.

The thermal conductivity of nanocomposite foams $\left(\lambda_{\mathrm{f}}\right)$ can be assumed as a contribution of four factors [34]: thermal conduction through the solid nanocomposite $\left(\lambda_{\mathrm{s}}\right)$, conduction through the gas phase $\left(\lambda_{\mathrm{g}}\right)$, convection through the cells $\left(\lambda_{\mathrm{cv}}\right)$ and radiation through the cell struts and across the cell voids $\left(\lambda_{\mathrm{r}}\right)$ :

$$
\lambda_{\mathrm{f}}=\lambda_{\mathrm{s}}+\lambda_{\mathrm{g}}+\lambda_{\mathrm{cv}}+\lambda_{\mathrm{r}}
$$

The thermal conductivity due to convection $\left(\lambda_{\mathrm{cv}}\right)$ is only considered significant when the Grashof number is greater than 1000 , which requires a minimum cell size of $10 \mathrm{~mm}[35,36]$; therefore, it can be ignored for these foams.

Regarding the contribution of radiation $\left(\lambda_{\mathrm{r}}\right)$, the heat flux going through the foam in radiation form can be modeled as radiation across a series of parallel opaque surfaces with a separation equal to the average cell size $(\Phi)$ according to [34]:

$$
\lambda_{\mathrm{r}}=4 \frac{\varepsilon}{2-\varepsilon} \sigma T^{3} \Phi,
$$

where $\varepsilon$ is the cell wall emissivity and $\sigma$ is the Stefan-Boltzmann constant. The radiation contribution can also be disregarded for the foams presented in this work, as all of them are black due to the presence of $\mathrm{GnP}$ and have been prepared with relatively high thicknesses. Since the conductive GnP particles play a key role in the final thermal conduction behavior of the foams, a two-phase model was suggested for predicting thermal conductivity:

$$
\lambda_{\mathrm{f}}=\lambda_{\mathrm{g}} V_{\mathrm{g}}+\xi\left(\lambda_{\mathrm{c}} V_{\mathrm{c}}\right)
$$

in which $\lambda_{\mathrm{f}}$ represents the thermal conductivity of the foam, $\lambda_{\mathrm{g}}$ corresponds to the conductivity of the gas in the cells $\left(\lambda_{\text {air }}=0.026 \mathrm{~W} \cdot \mathrm{m}^{-1} \cdot \mathrm{K}^{-1}[37]\right), \lambda_{\mathrm{c}}$ represents the conductivity of the solid nanocomposite 
phase (PSU-GnP, experimentally determined to be between $0.210 \mathrm{~W} \cdot \mathrm{m}^{-1} \cdot \mathrm{K}^{-1}$ for unfilled PSU and 0.282 $\mathrm{W} \cdot \mathrm{m}^{-1} \cdot \mathrm{K}^{-1}$ for PSU-GnP foams containing the highest amount of $\mathrm{GnP}$ ) and $\xi$ is a parameter related to the tortuosity, which depends on the complexity of the foam's structure. $V_{\mathrm{g}}$ and $V_{\mathrm{c}}$ correspond to the volume fraction of the gas and solid phase, respectively.

As can be seen when comparing the SEM micrographs presented in Figures 3-5, and in Figures 7-9, and the cellular structure characteristics presented in Table 1, the changes in cellular structure could alter the tortuosity factor $\xi$, directly affecting the values of thermal conductivity; therefore, the $\xi \lambda_{\mathrm{c}}$ product was calculated from the experimental thermal conductivity values for each foam using the following equation and presented in Table 3:

$$
\xi \lambda_{\mathrm{c}}=\frac{\lambda_{\mathrm{f}}-\lambda_{\mathrm{g}} V_{\mathrm{g}}}{V_{\mathrm{c}}}
$$

Table 3. Tortuosity effect $\left(\xi \lambda_{c}\right)$ and foaming efficiency $(n)$ influence on the thermal conductivity of PSU and PSU-GnP nanocomposite foams.

\begin{tabular}{|c|c|c|c|c|}
\hline Foam Series & $\mathrm{GnP}(w t \%)$ & $\xi \lambda_{\mathrm{c}}\left(\mathrm{W} \cdot \mathrm{m}^{-1} \cdot \mathrm{K}^{-1}\right)$ & Relative Density & $n$ \\
\hline \multirow{5}{*}{ Series 1} & 0 & 0.150 & 0.24 & 0.692 \\
\hline & 1 & 0.192 & 0.28 & 0.764 \\
\hline & 2 & 0.184 & 0.30 & 0.760 \\
\hline & 5 & 0.294 & 0.32 & 0.847 \\
\hline & 10 & 0.459 & 0.39 & 0.909 \\
\hline \multirow{5}{*}{ Series 2} & 0 & 0.138 & 0.35 & 0.712 \\
\hline & 1 & 0.225 & 0.32 & 0.806 \\
\hline & 2 & 0.248 & 0.41 & 0.840 \\
\hline & 5 & 0.490 & 0.42 & 0.918 \\
\hline & 10 & 1.093 & 0.45 & 0.964 \\
\hline \multirow{7}{*}{ Series 3} & 0 & 0.168 & 0.36 & 0.760 \\
\hline & 0.1 & 0.159 & 0.35 & 0.744 \\
\hline & 0.4 & 0.194 & 0.37 & 0.791 \\
\hline & 0.7 & 0.185 & 0.38 & 0.785 \\
\hline & 1.0 & 0.185 & 0.41 & 0.791 \\
\hline & 1.5 & 0.192 & 0.46 & 0.808 \\
\hline & 2.0 & 0.209 & 0.45 & 0.821 \\
\hline
\end{tabular}

The effect of changes in tortuosity could be observed in foams with similar composition. In the case of foams prepared using the WVIPS method, the ones with an open-cell structure (15 PSU $10 \mathrm{GnP}$, 25 PSU $5 \mathrm{GnP}$ and 25 PSU $10 \mathrm{GnP}$ ) showed considerably lower tortuosity (higher $\xi \lambda_{\mathrm{c}}$ values) and, as a consequence, displayed higher values of thermal conductivity. For foams with closed-cell structure, the value of the specific thermal conductivity decreased with decreasing cell size and hence increasing cell nucleation density, directly related to a higher tortuosity.

The drawback in the two-phase model presented in Equation (5) is that the effect of foam's density on the thermal conductivity of the foam is not clearly introduced. The already shown increase in thermal conductivity of the foam by incrementing relative density (Figure 11) can be explained by a power law expression similar to the one suggested by Gibson and Ashby for predicting the mechanical performance of cellular solids [35]:

$$
\frac{\lambda_{\mathrm{f}}}{\lambda_{\mathrm{c}}}=K\left(\frac{\rho}{\rho_{\mathrm{s}}}\right)^{n}
$$

In this equation, if we assume $K$ as being a variable equivalent to the tortuosity parameter $\xi$, exponent $n$ can be seen as representing the foaming efficiency in the final thermal conductivity, being related to the relative density according to: 


$$
n=\frac{\left[\ln \left(\lambda_{\mathrm{f}}\right)-\ln \left(\xi \lambda_{\mathrm{c}}\right)\right]}{\left[\ln \left(\frac{\rho}{\rho_{\mathrm{s}}}\right)\right]} .
$$

The values of $n$ have been calculated for each foam and are presented in the final column of Table 3. As the values of $n$ suggest, the highest efficiency corresponds to the foams from series 2, i.e., foams prepared by the WVIPS method with a $25 \%$ of PSU.

These results, combined with the previous analysis on the tortuosity and cellular structure of the foams, could lead to an optimization of the thermal conductivity of PSU-GnP nanocomposite foams by controlling their density and cellular structure, and hence to the achievement of highly conductive foams at lower amounts of GnP. This can be more clearly seen in Figure 13 by representing the normalized thermal conductivity of the foams $\left(\lambda_{\text {norm }}\right)$, calculated by dividing $\lambda_{\mathrm{f}}$ by $\left(\xi \lambda_{\mathrm{c}}\right)$, as a function of relative density.

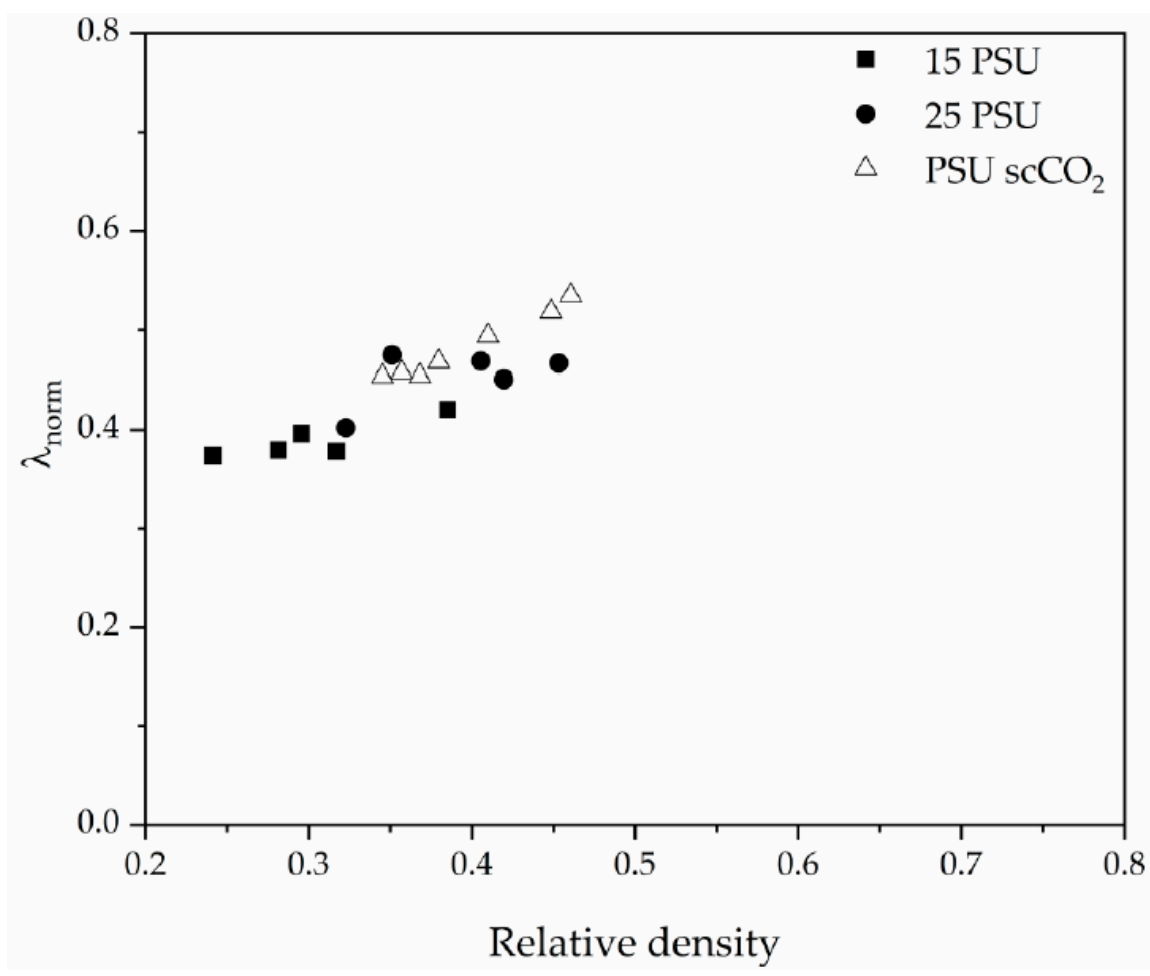

Figure 13. Normalized thermal conductivity evolution with relative density for PSU and PSU-GnP nanocomposite foams.

\section{Conclusions}

Three series of PSU-GnP nanocomposite foams with variable amounts of GnP (between 0 and 10 $\mathrm{wt} \%$ ) were prepared using two foaming methods: WVIPS and $\mathrm{scCO}_{2}$ dissolution. Foams prepared by the WVIPS method presented relative densities between $0.24-0.39$ for series 1 (foams prepared with $15 \%$ PSU) and between $0.35-0.45$ for series 2 (foams prepared with $25 \%$ PSU), while foams prepared by $\mathrm{scCO}_{2}$ dissolution (series 3 ) displayed relative densities between $0.36-0.45$. In all series, relative density increased with incrementing the amount of GnP.

In terms of cellular structure, foams from series 1 and series 2 showed higher average cell sizes and hence lower cell densities and cell nucleation densities with the addition of GnP. Among these foams, those with lower amounts of $\mathrm{GnP}$ displayed a homogenous closed-cell structure, whereas those with a higher $\mathrm{GnP}$ concentration (10 $\mathrm{wt} \% \mathrm{GnP}$ in series 1 and 5 and $10 \mathrm{wt} \% \mathrm{GnP}$ in series 2$)$ showed an open-cell interconnected structure. These results suggest that the presence of $\mathrm{GnP}$ affected the kinetics during the phase separation exchange process by slowing it down due to the affinity of GnP for NMP. In the case of foams prepared via $\mathrm{scCO}_{2}$ dissolution, an opposite trend was observed with only slight 
changes. The average cell size of foams from series 3 slightly decreased by adding GnP, which could be the result of a physical barrier effect of the platelet-like GnP to the diffusion of $\mathrm{CO}_{2}$ in $\mathrm{PSU}$.

The thermal conductivity of the foams was affected mainly by the presence of GnP, the cellular structure, and the density of the foams. The thermal conductivity showed a linear increasing trend with increasing GnP volume fraction, as expected due to the intrinsically high thermal conductivity of GnP. Additionally, the tortuosity of the cellular structure, also directly related to the added amount of GnP, influenced the final value of thermal conductivity by affecting the path of conduction. The highest values of thermal conductivity corresponded to foams with an open-cell interconnected structure. Moreover, density played a key role, as thermal conductivity followed a power law relation with relative density. The combination of these factors showed that PSU-GnP foams can be prepared with higher thermal conductivity at a lower amount of $\mathrm{GnP}$ by carefully controlling their cellular structure and relative density.

Author Contributions: Formal analysis: H.A., M.A., and J.I.V.; investigation: H.A., M.A., and J.I.V.; methodology: H.A., and M.A.; writing — original draft: H.A., M.A., and J.I.V.; writing—review and editing: H.A., M.A., and J.I.V. All authors have read and agreed to the published version of the manuscript.

Funding: Research funded by the Spanish Ministry of Science, Innovation, and Universities, Government of Spain (project MAT2017-89787-P).

Conflicts of Interest: The authors declare no conflict of interest.

\section{References}

1. McKeen, L.W. 12-High Temperature/High Performance Polymers. In Plastics Design Library; William Andrew Publishing: Boston, MA, USA, 2012; pp. 315-337. ISBN 978-1-4557-2551-9.

2. Gohil, S.V.; Suhail, S.; Rose, J.; Vella, T.; Nair, L.S. Polymers and composites for orthopedic applications. In Materials for Bone Disorders; Elsevier: Amsterdam, The Netherlands, 2017; pp. 349-403.

3. Kyriacos, D. High-Temperature Engineering Thermoplastics. In Brydson's Plastics Materials; Elsevier: Amsterdam, The Netherlands, 2017; pp. 545-615.

4. Krause, B.; Diekmann, K.; van der Vegt, N.F.A.; Wessling, M. Open Nanoporous Morphologies from Polymeric Blends by Carbon Dioxide Foaming. Macromolecules 2002, 35, 1738-1745. [CrossRef]

5. Li, Z.; Jia, Y.; Bai, S. Polysulfone foam with high expansion ratio prepared by supercritical carbon dioxide assisted molding foaming method. RSC Adv. 2018, 8, 2880-2886. [CrossRef]

6. Guo, H.; Nicolae, A.; Kumar, V. Solid-state microcellular and nanocellular polysulfone foams. J. Polym. Sci. Part B Polym. Phys. 2015, 53, 975-985. [CrossRef]

7. Sun, H.; Mark, J.E. Preparation, characterization, and mechanical properties of some microcellular polysulfone foams. J. Appl. Polym. Sci. 2002, 86, 1692-1701. [CrossRef]

8. Krause, B.; Boerrigter, M.E.; van der Vegt, N.F.A.; Strathmann, H.; Wessling, M. Novel open-cellular polysulfone morphologies produced with trace concentrations of solvents as pore opener. J. Memb. Sci. 2001, 187, 181-192. [CrossRef]

9. Huang, Q.; Klötzer, R.; Seibig, B.; Paul, D. Extrusion of microcellular polysulfone using chemical blowing agents. J. Appl. Polym. Sci. 1998, 69, 1753-1760. [CrossRef]

10. Wu, H.; Tang, B.; Wu, P. Development of novel $\mathrm{SiO}_{2}-\mathrm{GO}$ nanohybrid/polysulfone membrane with enhanced performance. J. Memb. Sci. 2014, 451, 94-102. [CrossRef]

11. Chakrabarty, B.; Ghoshal, A.K.; Purkait, M.K. Ultrafiltration of stable oil-in-water emulsion by polysulfone membrane. J. Memb. Sci. 2008, 325, 427-437. [CrossRef]

12. Anadão, P.; Sato, L.F.; Wiebeck, H.; Valenzuela-Díaz, F.R. Montmorillonite as a component of polysulfone nanocomposite membranes. Appl. Clay Sci. 2010, 48, 127-132. [CrossRef]

13. Devrim, Y.; Erkan, S.; Baç, N.; Eroğlu, I. Preparation and characterization of sulfonated polysulfone/titanium dioxide composite membranes for proton exchange membrane fuel cells. Int. J. Hydrog. Energy 2009, 34, 3467-3475. [CrossRef]

14. Lawal, A.T. Graphene-based nano composites and their applications: A review. Biosen. Bioelectron. 2019, 141, 111384. [CrossRef] [PubMed]

15. Antunes, M.; Realinho, V.; Velasco, J.I. Foaming behaviour, structure, and properties of polypropylene nanocomposites foams. J. Nanomater. 2010, 2010, 4. [CrossRef] 
16. King, J.A.; Tucker, K.W.; Vogt, B.D.; Weber, E.H.; Quan, C. Electrically and thermally conductive nylon 6, 6. Polym. Compos. 1999, 20, 643-654. [CrossRef]

17. Verdejo, R.; Barroso-Bujans, F.; Rodriguez-Perez, M.A.; De Saja, J.A.; Lopez-Manchado, M.A. Functionalized graphene sheet filled silicone foam nanocomposites. J. Mater. Chem. 2008, 18, 2221-2226. [CrossRef]

18. Han, Z.; Fina, A. Thermal conductivity of carbon nanotubes and their polymer nanocomposites: A review. Prog. Polym. Sci. 2011, 36, 914-944. [CrossRef]

19. Fraleoni-Morgera, A.; Chhikara, M. Polymer-based nano-composites for thermal insulation. Adv. Eng. Mater. 2019, 21, 1801162. [CrossRef]

20. Gedler, G.; Antunes, M.; Borca-Tasciuc, T.; Velasco, J.I.; Ozisik, R. Effects of graphene concentration, relative density and cellular morphology on the thermal conductivity of polycarbonate-graphene nanocomposite foams. Eur. Polym. J. 2016, 75, 190-199. [CrossRef]

21. Fukushima, H.; Drzal, L.; Rook, B.; Rich, M. Thermal conductivity of exfoliated graphite nanocomposites. J. Therm. Anal. Calorim. 2006, 85, 235-238. [CrossRef]

22. Gonnet, P.; Liang, Z.; Choi, E.S.; Kadambala, R.S.; Zhang, C.; Brooks, J.S.; Wang, B.; Kramer, L. Thermal conductivity of magnetically aligned carbon nanotube buckypapers and nanocomposites. Curr. Appl. Phys. 2006, 6, 119-122. [CrossRef]

23. Gu, J.; Yang, X.; Lv, Z.; Li, N.; Liang, C.; Zhang, Q. Functionalized graphite nanoplatelets/epoxy resin nanocomposites with high thermal conductivity. Int. J. Heat Mass Transf. 2016, 92, 15-22. [CrossRef]

24. Shtein, M.; Nadiv, R.; Buzaglo, M.; Kahil, K.; Regev, O. Thermally conductive graphene-polymer composites: Size, percolation, and synergy effects. Chem. Mater. 2015, 27, 2100-2106. [CrossRef]

25. Yang, J.; Zhang, E.; Li, X.; Zhang, Y.; Qu, J.; Yu, Z.-Z. Cellulose/graphene aerogel supported phase change composites with high thermal conductivity and good shape stability for thermal energy storage. Carbon 2016, 98, 50-57. [CrossRef]

26. Wang, F.; Drzal, L.T.; Qin, Y.; Huang, Z. Mechanical properties and thermal conductivity of graphene nanoplatelet/epoxy composites. J. Mater. Sci. 2015, 50, 1082-1093. [CrossRef]

27. Hu, L.; Desai, T.; Keblinski, P. Thermal transport in graphene-based nanocomposite. J. Appl. Phys. 2011, 110, 33517. [CrossRef]

28. Abbasi, H.; Antunes, M.; Velasco, J.I.I. Graphene nanoplatelets-reinforced polyetherimide foams prepared by water vapor-induced phase separation. eXPRESS Polym. Lett. 2015, 9, 412-423. [CrossRef]

29. Abbasi, H.; Antunes, M.; Velasco, J.I.I. Enhancing the electrical conductivity of polyetherimide-based foams by simultaneously increasing the porosity and graphene nanoplatelets dispersion. Polym. Compos. 2018, 40, E1416-E1425. [CrossRef]

30. Abbasi, H.; Antunes, M.; Velasco, J.I. Polyetherimide foams filled with low content of graphene nanoplatelets prepared by $\mathrm{scCO}_{2}$ dissolution. Polymers 2019, 11, 328. [CrossRef]

31. Abbasi, H.; Antunes, M.; Velasco, J.I. Effects of Carbon Nanotubes/Graphene Nanoplatelets Hybrid Systems on the Structure and Properties of Polyetherimide-Based Foams. Polymers 2018, 10, 348. [CrossRef]

32. Liang, C.Z.; Chung, T.-S.; Lai, J.-Y. A review of polymeric composite membranes for gas separation and energy production. Prog. Polym. Sci. 2019, 97, 101141. [CrossRef]

33. Sims, G.L.A.; Khunniteekool, C. Cell-size measurement of polymeric foams. Cell. Polym. 1994, 13, $137-146$.

34. Glicksman, L.R. Heat transfer in foams. In Low Density Cellular Plastics. Physical Basis of Behaviour; Chapman \& Hall: London, UK, 1994; pp. 104-152.

35. Gibson, L.J.; Ashby, M.F. Cellular Solids: Structure and Properties; Cambridge University Press: Cambridge, UK, 1999; ISBN 131602542X.

36. Holman, J.P. Heat Transfer; McGraw-Hill: New York, NY, USA, 2010; ISBN 0071267697.

37. Weast, R.C.; Astle, M.J.; Beyer, W.H. Handbook of Chemistry and Physics; CRC Press: Boca Raton, FL, USA, 1988; Volume 69.

(C) 2019 by the authors. Licensee MDPI, Basel, Switzerland. This article is an open access article distributed under the terms and conditions of the Creative Commons Attribution (CC BY) license (http://creativecommons.org/licenses/by/4.0/). 